\title{
9. 自然エネルギー
}

\section{1 地熱発電の動向}

\section{1. わが国の現状}

昭和58年12月末現在, わが国で稼動している地熱発 電所は表 9-1 飞示す 9 発電所であるが，この中には58 年10月から試運転を始めた霧島国際ホテル地熱発電所 $100 \mathrm{~kW}$ 新たに加わっている。(ただし営業運転は59年 2 月23日に開始されている)

同発電所は 56 年 8 月運転開始した別府市・杉乃井地 熱発電所 $3,000 \mathrm{~kW}$ のように, 温泉地に打碑る自家発電 のための中小規模地熱（ミ三地熱）として開発された ものであり, その概要は次の通りである。

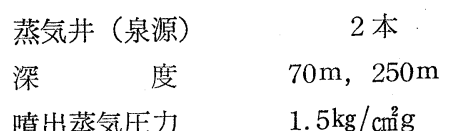

噴出蒸気圧力 $\quad 1.5 \mathrm{~kg} / \mathrm{cm}^{2} g$

$$
\begin{array}{cl}
\text { 噴出蒸気温度 } & 126.8^{\circ} \mathrm{C} \\
\text { " 使用量 } & 6.25 \mathrm{~m}^{3} / \mathrm{H}
\end{array}
$$

発電設備（富士電機製）

$\begin{array}{lll}\text { タービン型式 } & \text { 衝動式脊圧形 } \\ \text { " } & \text { 出力 } & 100 \mathrm{~kW} \\ \text { " } & \text { 気筒数 } & 1 \\ \text { " } & \text { 入口蒸気圧力 } & 1.5 \mathrm{~kg} / \mathrm{cm}^{2} \mathrm{~g} \\ \text { " } & \text { " 温度 } & 126.8^{\circ} \mathrm{C} \\ \text { " } & \text { 排気圧力 } & 0 \mathrm{~kg} / \mathrm{cm}^{2} \mathrm{~g} \\ \text { " } & \text { 回転数 } & 3,600 \mathrm{r} \cdot \mathrm{p} \cdot \mathrm{m} .\end{array}$

発電機型式

" 容量 $125 \mathrm{KVA}$

" 力率 $80 \%$ (遅れ)

" 電圧 $440 \mathrm{~V}$

" 周波数 $60 \mathrm{~Hz}$

この添か八丁原, 葛根田との他の地域に拉いて各デ ベロッパーにより鋭意，増設または開発のための努力

表 9-1 わが 国の地熱 発電 所（運転中のもの）

\begin{tabular}{|c|c|c|c|c|c|c|}
\hline 発 電 所 名（会社名） & $\begin{array}{c}\text { 設備容量 } \\
\mathrm{kW}\end{array}$ & $\begin{array}{c}\text { 認可容量 } \\
\mathrm{kW}\end{array}$ & $\begin{array}{c}\text { (1)発電電力量 } \\
\mathrm{kWh}\end{array}$ & $\begin{array}{c}\text { (2)最大電力 } \\
\mathrm{kW}\end{array}$ & $\begin{array}{l}\text { (3)稼動率 } \\
\%\end{array}$ & $\begin{array}{l}\text { (4)負荷率 } \\
\%\end{array}$ \\
\hline 松 川（日本重化学(森） & 22,000 & 22,000 & $176,643,300$ & 23,100 & 96.4 & 87.3 \\
\hline 大 岳（九州電力怢） & 13,000 & 12,500 & $79,194,000$ & 10,200 & 100 & 88.6 \\
\hline 大 沼（三菱金属 (侏) & 10,000 & 8,700 & $61,494,100$ & 8,700 & 96.4 & 80.7 \\
\hline 鬼 首（電 源開 発 (株) & 25,000 & 12,500 & $69,207,000$ & 11,000 & 94.5 & 71.8 \\
\hline 八丁原（九州電力㑣） & 55,000 & 55,000 & $453,981,000$ & 55,000 & 100 & 94.2 \\
\hline 葛根 田 $\left(\begin{array}{l}\text { 日本重化学(侏 } \\
\text { 電力森 }\end{array}\right)$ & 50,000 & 50,000 & $370,928,000$ & 50,600 & 95.3 & 83.7 \\
\hline 杉乃井（烌杉乃井ホテル） & 3,000 & 3,000 & $19,816,020$ & 2,630 & 97.3 & 52.27 \\
\hline 森( $\left(\begin{array}{l}\text { 道南地熱エネルギー湘 } \\
(\text { 海 電 力 }\end{array}\right.$ & 50,000 & 50,000 & $183,153,000$ & 40,000 & 89.03 & 93.8 \\
\hline $\begin{array}{r}\text { 霧島国際ホテル } \\
\text { (大和紡観光(㛦) }\end{array}$ & 100 & - & 58,047 & 74 & 18 & 68 \\
\hline 計 & 228,100 & 213,700 & $1,414,474,000$ & - & - & - \\
\hline
\end{tabular}

(1983年12月31日現在)

注(1) 発電出力は昭和58年 1 月 1 日〜同年12月 31 日の 1 年分

(2) 最大電力は 1 時間最大

(3) 稼動率は（稼動日数 $/ 365) \times 100 \%$

(4) 負荷率は (暦日平均電力 $/$ 最大電力) $\times 100 \%$ また霧島国際ホテル地熱発電所については昭和58年10月23日試運転開始, 59 年 2 月 23 日 $100 \mathrm{~kW}$ 営業運転開 始のため, 本表の数字は試運転中のものである。 
がなされている。

58 年の発電電力量実績については, 前年の $1,203 \times$ $10^{6} \mathrm{kWh}$ に比較すると約 $20 \%$ の増加を示し，森地熱発 電所加入の影響が大きいことを示している。

な抽58年中の全地熱発電所を総合した平均稼動率, 負荷率を計算すると $94.3 \%, 80.3 \%$ と高い值を示し， 運転開始以来18年を経過した松川地熱発電所を含めて 各発電所とも順調な運転を続けており, 設備上の信頼 度と共に周辺環境への適応性についても支障のなかっ たことを実証している。

\section{2. 海外の動向}

表 9-2 に世界の地熱発電の現況を揭げたが 1 年前の 設備容量合計 2, 716.3MW に比較して約 $20 \%$ の増加が みられている。

Geysers 発電所の設備容量が PG\&E 17, 18 号プラ ント (各110MW), NCPA 2 号プラント(106MW)の 完成により $1,000 \mathrm{MW}$ の大台を越した 米国は，世界の 合計容量の約40\%を占めるに至って和り，依然として 世界最大の地熱開発国である。

ここ数年目ざましい発展を続けているフィリピンは 19\%で第 2 位を占め, 以下イタリア $14 \%$, 日本 $7 \%$ で 3,4 位と続くのは前年通りであるが，メキシコがLos Azufres 25MW の開発によりニュージーランドを抜 いて 5 位に浮び上っている。

一方，わが国の地熱発電設備メーカーに対する海外 の地熱開発諸国からの需要は, 納入設備の安定した運 転実績が信頼をよんで引続き順調な 伸びを示してい る。

現在，海外地熱発電プラント（主機）の納入実績を 有するわが国のメ一カ一は㑣東芝, 三菱重工業(㑣), 富 士電機製造(株の 3 社であるが，他の地熱発電プラント ・メーカーも将来の受注に備えている。 表 9-3に1983年末現在にお和海外への地熱発電プ ラント納入実績を示す。

\section{3. 地熱調查活動}

財)新エネルギー総合開発機構は通商産業者の補助お よび委託を受けて地熱開発推進のための諸事業を行っ ている。その地熱調査事業のうち，ここでは地熱井の 掘削調査に着目してとり上げると次の通りである。な 抏ここでは昭和58年 1 月より12月末までの間に掘削完 了したものを揭げる。

（1）地熱開発促進調査

この調査は地熱開発に伴う探査りスクなどにより民 間が手を付けていない，地熱発電の観点から有望な地 域について国が先導的に行らものである。対象となっ
表 9-2 世界の地熱発電の現況（1983年 6 月）

\begin{tabular}{|c|c|c|}
\hline 国 名, 地 域 & $\begin{array}{l}\text { 設備容量 } \\
\text { (MW) }\end{array}$ & $\begin{array}{l}\text { 国 別 計 } \\
(\mathrm{MW})\end{array}$ \\
\hline 米国，Geysers* & 1,246 & $(1,283.7)$ \\
\hline East Mesa & 12.2 & \\
\hline Brawley & 10 & \\
\hline Puna & 3 & \\
\hline Salton Sea & 10 & \\
\hline Roosevelt & 1.6 & \\
\hline Hammersly Canyon & 0.9 & \\
\hline フィリピン, Tongonan** & 40.5 & $(593.5)$ \\
\hline Tiwi & 330 & \\
\hline \multirow{2}{*}{$\begin{array}{l}\text { Mak-Ban } \\
\text { Palimpinon* }\end{array}$} & 220 & \\
\hline & 3 & \\
\hline イタリア，Larderello & 169 & $(457.1)$ \\
\hline Castelnuovo & 50 & \\
\hline Serrazzano & 47 & \\
\hline Lago & 33.5 & \\
\hline 他 & 157.6 & \\
\hline 日本 & 228 & (228) \\
\hline \multirow{2}{*}{$\begin{array}{r}\text { メシコ, Cerro Prieto } \\
\text { Los Azufres } \\
\end{array}$} & 180 & (205) \\
\hline & 25 & \\
\hline \multirow{2}{*}{ 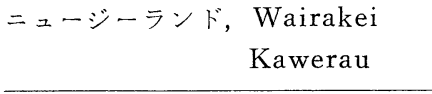 } & 192.6 & $(202.6)$ \\
\hline & 10 & \\
\hline エルサルバドル, Ahuachapán & 95 & (95) \\
\hline アイスランド, Námafjall & 3 & (41) \\
\hline $\begin{array}{l}\text { Krafla } \\
\text { Svartsengi }\end{array}$ & 30 & \\
\hline Svartsengi & 8 & \\
\hline インドネシア, Kamojang & 30.25 & $(32.25)$ \\
\hline Dieng & 2 & \\
\hline ケニア, Olkaria & 30 & (30) \\
\hline ソ連, Pauzhetka & 11 & (11) \\
\hline 中国, Yangbajing 他 & 5.136 & $6(5.136)$ \\
\hline 台湾, Chingshui & 3 & (3) \\
\hline \multicolumn{2}{|l|}{ ポルトガル(アゾレス), } & (3) \\
\hline Pico Vermelho & 3 & \\
\hline トルコ, Kizildere & 0.5 & $(0.5)$ \\
\hline \multicolumn{2}{|l|}{ 計 } & $3,190.8$ \\
\hline \multicolumn{3}{|c|}{$\begin{array}{l}\text { * このあと Geysers で } 1983 \text { 年中に SMUDGEO } \\
\text { №.172MWが完成 } \\
\text { ** 1983年 } 9 \text { 月までに } 37.5 \mathrm{MW} \text { のユニットが Tong- }\end{array}$} \\
\hline \multicolumn{3}{|c|}{$\begin{array}{l}\text { ** 1983年 } 9 \text { 月までに } 37.5 \mathrm{MW} \text { のユニットが Tong- } \\
\text { onan にて } 2 \text { 基, Palimpinon にて } 3 \text { 基完成 }\end{array}$} \\
\hline
\end{tabular}


表 9-3 わが国の発電プラントメーカーの海外からの地熱用蒸気タービン等主機受注状況

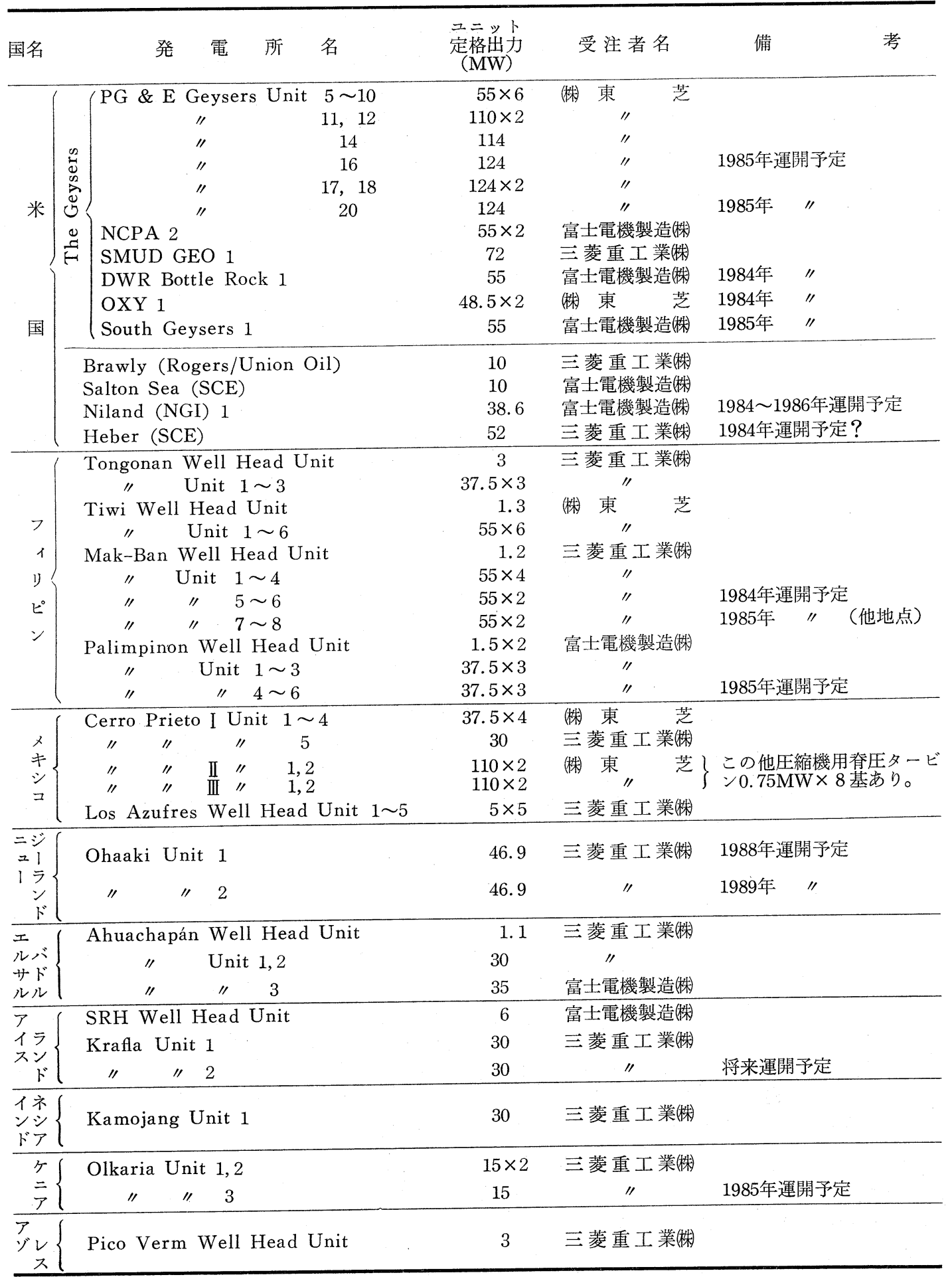




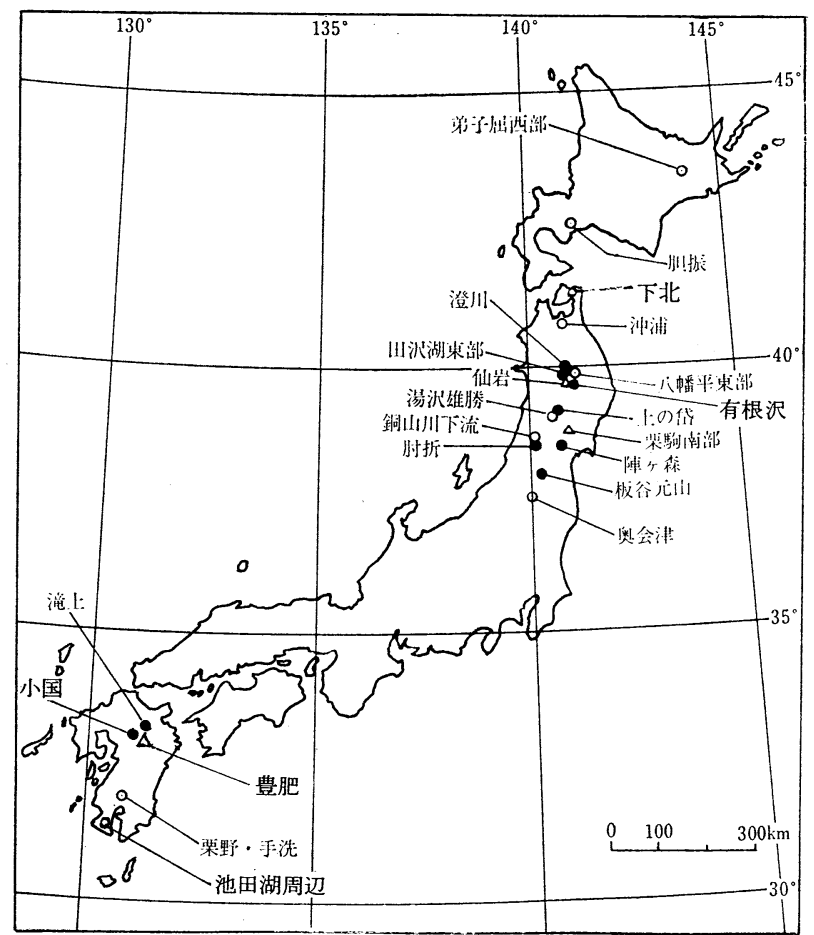

図 9-1 地熱調査（ボーリング）が行われた地域

（印以外の企業調査地域は含まれていない）

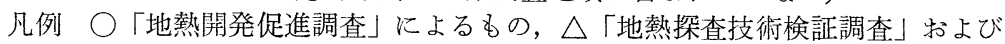
「大規模深部調査」によるもの

○「地熱発電所調査井掘削費等補助金」の交付をらけたもの

た地域と坑井は次の通りである。

1) 北海道弟子屈西部地域 $(1800 \mathrm{~m}$ 深 $\times 1 ， 1500 \mathrm{~m}$ 深 $\times 1)$

2 ) 北海道胆振地域 $(1000 \mathrm{~m}$ 深 $\times 1)$

3 ) 青森県下北地域 (1000m深 $\times 1$, な $\times 3$ が年度内に完了予定)

4 ) 秋田県湯沢雄勝地域 $(350 \mathrm{~m}$ 深 $\times 1,500 \mathrm{~m}$ 深 $\times 1$, $1000 \mathrm{~m}$ 深 $\times 1$ ， $1500 \mathrm{~m}$ 深 $\times 3$ ，な打 $1200 \mathrm{~m}$ 深 $\times 1$ と $1800 \mathrm{~m}$ 深 $\times 1$ が年度内に完了予定）

5 ) 福島県奥会津地域 $(1000 \mathrm{~m}$ 深 $\times 2,1500 \mathrm{~m}$ 深 $\times 2)$

6 ) 鹿児島県池田湖周辺地域 $(1000 \mathrm{~m}$ 深 $\times 2$ と $1500 \mathrm{~m}$ 深 $\times 2$ 年度内に完了予定）

（2）大規模深部地熱発電所環境保全実証調查 九州の熊本県および大分県に亘る豊肥地熱地域にお いて広域の深部地熱構造を把握し, 大規模発電の可能 性を探ると共に，あわせて地熱流体の採取・還元とそ の環境への影響を調査する目的のものである。

1) 大分県豊肥地域 $(1550 \mathrm{~m}$ 深 $\times 1)$

2 ) 熊本県豊肥地域 $(1800 \mathrm{~m}$ 深 $\times 1)$
（3）地熱探查技術等検証調査

岩手・秋田両県下に亘る仙岩地域と宮城県栗駒南部 地域を対象とし物理探査による地下探査を行いその結 果を坑井掘削により検証する。これにより探査技術の 向上をはかる計画である。次の掘削が行われた。

1) 仙岩地域 $(400 \mathrm{~m}$ 深 $\times 2$, な特 $1500 \mathrm{~m}$ 深 $\times 3$ が年 度内の計画で掘削中である）

以上新エネルギー総合開発機構の坑井掘削について のべたが，一通商産業省資源エネルギー庁では地熱 開発企業者に対し, 調査井の掘削について補助金の交 付を行い，地熱発電の実現促進をはかっている。補助 率は $1 / 2$ であり，この制度により本年中に掘削された坑 井は次頁の通りである。

な扣以上の他, 熊本県小国に拈いて電源開発森が $1800 \mathrm{~m} \times 1$ に着手しているが終了予定は 59年度にはい ってからである。

以上の他, 企業独自による掘削活動もあると考えら れるが，それらについては筆者の調べが行き届かな w。 


\begin{tabular}{|c|c|c|c|}
\hline 地 地熱 & 県名 & 開発企業名 & 坑井の深さと数 \\
\hline 有 根 沢 & 岩 & 出光地熱開発(侏 & $2200 \mathrm{~m} \times 1$ \\
\hline 上の岱 & 秋 & 同 和 鉱 業 (侏) & $1400 \mathrm{~m} \times 1$ \\
\hline 陣 ケ森 & 宮 & 電 源 開 発 & $\underset{\times 1}{1500 \mathrm{~m} \times 1, \quad 1800 \mathrm{~m}}$ \\
\hline 板谷元山 & 福 島 & 住友軽金属株 & $\begin{array}{l}1500 \mathrm{~m} \times 1 \text { が58年度 } \\
\text { 内完了予定 }\end{array}$ \\
\hline 滝 & 大 分 & 出光地熱開発(侏 & $\begin{array}{l}2300 \mathrm{~m} \times 1,1700 \mathrm{~m} \\
\times 1 さ ら に 2500 \mathrm{~m} \times 2 \\
\text { と3000m } \times 1 \text { が58年 } \\
\text { 度内完了予定 }\end{array}$ \\
\hline 霧 & 鹿児島 & $\begin{array}{l}\text { 新日鉄株特よび } \\
\text { 日鉄鉱森共同 }\end{array}$ & $\begin{array}{l}700 \mathrm{~m} \times 2,1500 \mathrm{~m} \times \\
2, \text { さらに } 1300 \mathrm{~m} \times 1 \\
\text { が } 58 \text { 年度内完了予定 }\end{array}$ \\
\hline
\end{tabular}

また以上を合計すると昭和 58 年 1 月 1 日より 12 月末 日の間に掘削完了した坑井の掘進延深度の計は36, 100 mに達する。

\section{2 太陽エネルギー利用の動向}

\section{1. まえがき}

石油事情の緩和と世界経済の停滞に伴って新エネル ギー開発の速度も世界的に鈍化の傾向を示している。 太陽エネルギーの場合も同様の動きが見られるが各国 の事情によりそれぞれの程度には差が見られる。

しかしながら 1982年のIE Aの 石油需給シナリオに よれば1990年頃には世界的に石油需要が石油供給を超 過する傾向が拡大して2000 年には 400 800 万 bbl/d の需給ギャップが生ずるとしており，長期的な見通し の観点から代替エネルギー資源の開発についてはゆる がせにできないどころかむしろ加速の必要があるもの と考光られる。

太陽エネルギーの研究開発の中でも最も早く実用化 の域に達した太陽冷喛房・給湯技術や後を追っている 太陽電池などの分野ではわが国は米国に次いで先進国 間でもリードカントリーとして目されており，その期 待を裏切らない努力を続ける必要がある。

\section{2. 太陽冷暖房・給湯システムの開発と実用化}

サンシャイン計画に和ける太陽泠暖房・給湯システ 么の研究開発は, 工業技術院名古屋工業技術試験所に おける太陽集熱器の評価システムの研究や集熱材料括 よび蓄熱材料の研究などの基礎研究，新エネルギー総 合開発機構に 委託した産業用ソーラーシステムの開 発, 土中蓄熱や化学反応蓄熱などの長期蓄熱等は前年
度に引き続いて進められている。

この中で産業用ソーラーシステムの内, 宮崎県農連 における種粐, 茶, 椎莫などの貯臓用定温倉庫が58年 8 月完成して試運転に入った。これは太陽エネルギー を利用して周年 $15^{\circ} \mathrm{C}$ の定温に保つもので，相対湿度も $50 \%$ 以下となっており，屋根一体型集熱器370枚，741 $\mathrm{m}^{2}$ と直膨式一重二重効用吸収冷凍機（10.6 USRT）を 組み合わせ, $75 \mathrm{~m}^{3}$ の温度成層型温水蓄熱槽が設けられ ている。システム構成を図 9-2 に示す。

また通産省生活産業局住宅産業課によるパッシブシ ステムおよび機器材料の開発も前年度に引き続いて進 められ, 一方通産大臣による優良ソーラーシステム構 成機器認定制度を創設して太陽集熱器と蓄熱槽の試験 を実施するため機械電子検査検定協会に委託して浜松

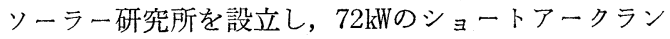
プによるソーラーシミュレータを完成して制度の発足 に備えている。図 9-3に可動式ソーラーシミュレータ の構成を示す。この試験装置は, 屋外に打ける太陽集 熱器の集熱性能試験が日射量, 風速, 気温などを始め 外界の擾乱の影響を受け易く，テストに長期間を要す ることから屋内試験を中心としたものである。な和昨 年11月改定されたJIS A 4111住宅用太陽熱利用温水 器もこのソーラーシミュレータによる屋内試験法を追 加することが決り日本住宅設備システム協会に和いて 再改定を行った。太陽熱温水器の昭和58年に和ける生 産台数は約 38 万 3 千台で昭和 55 年のピークを経て市況 の延び悩みはあるが，図 9-4 に示す通りほぼ横ばい状 態である。この中で自然循環式が主流を占め, 汲み置 き式は $1 \%$ 末満となっている。

またこれとは別に強制循環式ソーラーシステムの設 置件数は昭和 58 年末で表 9-4 に揭げる通りで約 17 万 8 千件となっており順調な延びを示している。これを地 域別に各通産局管区別に示すと図 9-5のようになり, 比較的日射量の豊富な関東以西にソーラーシステムの 設置件数の多いことがわかる。四国の少ないのは他の 地区に比較して人口の少ないことに帰因している。表 9-4括よび図9-5の件数の中には低利融資による戸建住 宅，集合住宅その他事業所ビルなどのソーラーシステ ムの設置件数も含んでいる。一方通産省生活産業局住 宅産業課による地方自治体の公的施設のソーラーシス テム化に対する補助金交付件数と予算額は表 9-5, お よび表 9-6にそれぞれ示してある。

ソーラーシステム振興協会では創立 5 週年の記念出 版を行い「伸びゆくソーラー日本」を刊行すると共に 優良登録工事店表彰や，9月末の睛見展示場に括ける 


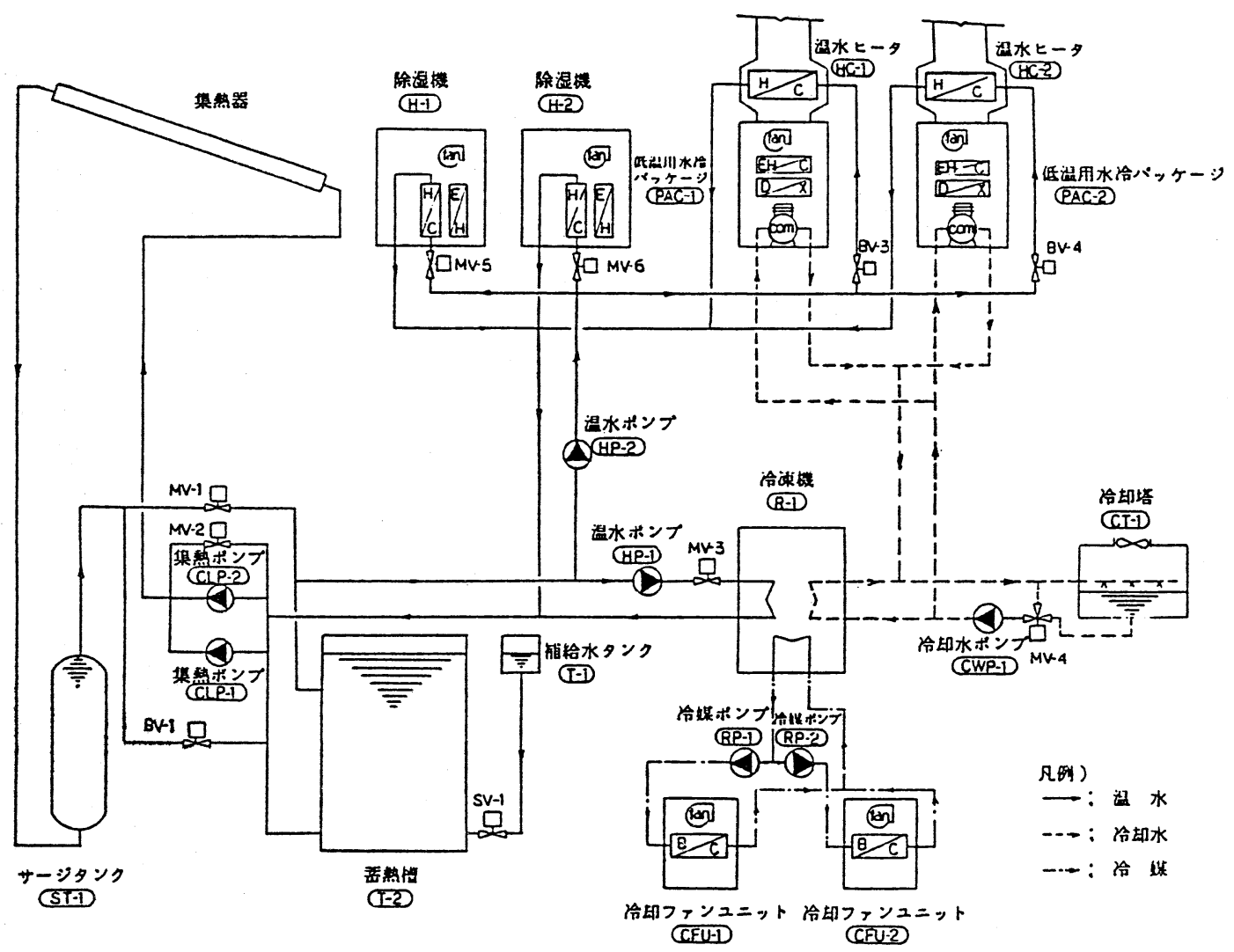

図 9-2 産業用ソーラーシステムフィックスト・ヒート・プロセス型の系統図

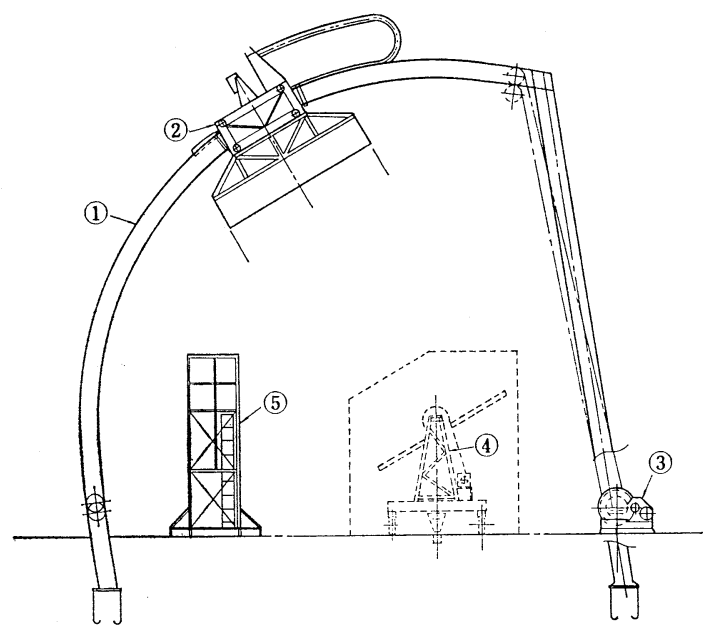
(1) アーチ鉄骨
(2) 光源装置
(3) 光源駆動装置
(4) 太陽集熱器架台
(5) ランプ整備台

図 9-3 ソーラーシミュレーター構成図
住宅設備展に協賛出品を行った。また工業技術院の委 託業務として太陽集熱器および蓄熱槽のJIS 化のため 原案作成を終了している。さらに太陽冷暖房ならびに 給湯システムのJIS 化のために建材試験センターに業 務委託を行い昭和 58 年より 5 年計画でシステムのJIS 規格案原案を作成することとなっている。

太陽熱脱塩技術に関しては, 機械システム振興協会 が香川県高見島に建設して試運転中であった真空管型 集熱器と多段フラッシュ蒸発機の組み合わせ抢よび平 板型集熱器と電気透析法の組み合わせの 2 方式の八イ ブリッドシステムの試験が 3 月終了し，地元に引き渡 された。これは今後日産 $10 \mathrm{t}$ の淡水を島民に供給して ゆく予定である。また新エネルギー総合開発機構に委 託されているアラブ首長国連邦における蒸発法による ソーラー脱塩の $100 \mathrm{t}$ プラントも敷地が確定して屁々 建設に乗り出すことになった。さらに造水センターで はニニークな多層型集熱器による太陽脱塩プラントを 沖縄の本部に建設して試運転を開始するなど太陽脱塩 


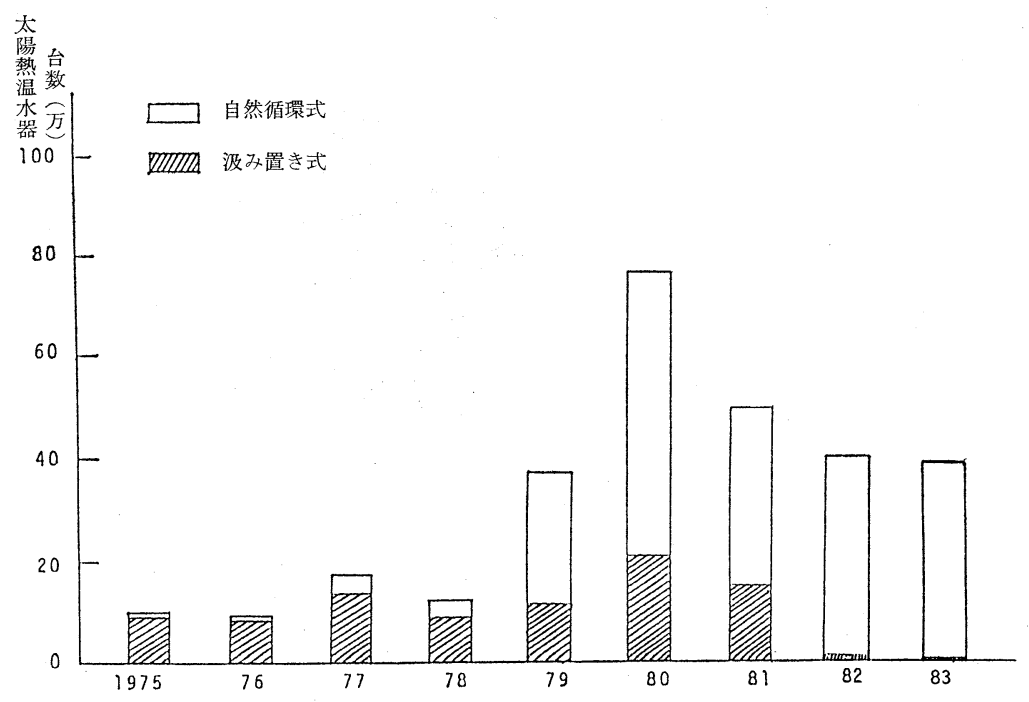

図 9-4 太陽熱温水器普及状況（昭和58年12月末現在）

表 9-4 ソーラーシステム (強制循環) 用途別, 年別販売・施工実績

(単位 : 件数)

\begin{tabular}{|c|c|c|c|c|c|c|c|c|c|}
\hline 用 & 年 & $\begin{array}{l}\text { 昭和 } \\
50 \sim 52 \\
\text { 年 } \\
\end{array}$ & 53 & 54 & 55 & 56 & 57 & 58 & 計 \\
\hline & 建 住 宅 & 914 & 927 & 2,305 & 24,420 & 30,525 & 50,428 & 63,165 & 172,684 \\
\hline \multirow{3}{*}{$\begin{array}{l}\text { 事 } \\
\text { 業 }\end{array}$} & 共同住宅 & 6 & 13 & 11 & 60 & 37 & 62 & 126 & 315 \\
\hline & $\begin{array}{l}\text { 若 生用 } \\
\text { 鄴 務 } \\
\text { (内公共用) }\end{array}$ & $\begin{array}{c}70 \\
(18)\end{array}$ & $\begin{array}{l}122 \\
(57)\end{array}$ & $\begin{array}{l}251 \\
(61)\end{array}$ & $\begin{array}{r}981 \\
(267)\end{array}$ & $\begin{array}{l}1,462 \\
(448)\end{array}$ & $\begin{array}{r}1,043 \\
(442)\end{array}$ & $\begin{array}{r}736 \\
(297)\end{array}$ & $\begin{array}{c}4,665 \\
(1,590)\end{array}$ \\
\hline & 産 業 用 & 4 & 12 & 13 & 69 & 55 & 32 & 54 & 239 \\
\hline \multirow{2}{*}{ 用 } & 計 & 80 & 147 & 275 & 1,110 & 1,554 & 1,137 & 916 & 5,219 \\
\hline & 総 & 994 & 1,074 & 2,580 & 25,530 & 32,079 & 51,565 & 64,081 & 177,903 \\
\hline
\end{tabular}

(ソーラーシステム振興協会調べ 昭58.12)

に関しても太陽冷暖房・給湯技術の延長線上の応用技 術として進展が見られた。

中小企業財団では水産加工団地への給湯用に北海道 網走地区に塩濃度勾配を有するソーラーポンドの建設 を計画し，昭和58年でフィージビリティスタディを終 了して建設に乗り出し, 同時にエンジニアリング振興 協会でこのポンドのシステム解析を開始している。

一方文部省でもエネルギー特別研究として太陽光に よる光合成の研究班の他に自然エネルギーの研究の中 に太陽エネルギー利用の研究と自然ェネルギーの複合 利用に関する研究が進められ, 太陽冷暖房・給湯に関
するものは12テーマに亘っている。

\section{3. 太陽熱発電技術}

四国香川県の仁尾町に 建設されたタワー方式 1,000 $\mathrm{kWe}$ 和よび平板一曲面集光方式 $1000 \mathrm{kWe}$ の 2 基の太 陽熱発電プラントは 2 年間の試験運転を経てそれらの 性能解析が終了した。これらのプラントは初期の目的 を達成したとして昭和58年より撤収に取りかかること になった。何れの方式も建設費がkW当り500万円近く， 他の商用発電型式と比較して約10分の 1 のコストダウ ンが要求される。この傾向は海外で建設された 6 プラ ントもすべて同様の傾向が見られ, 今後の研究課題の 


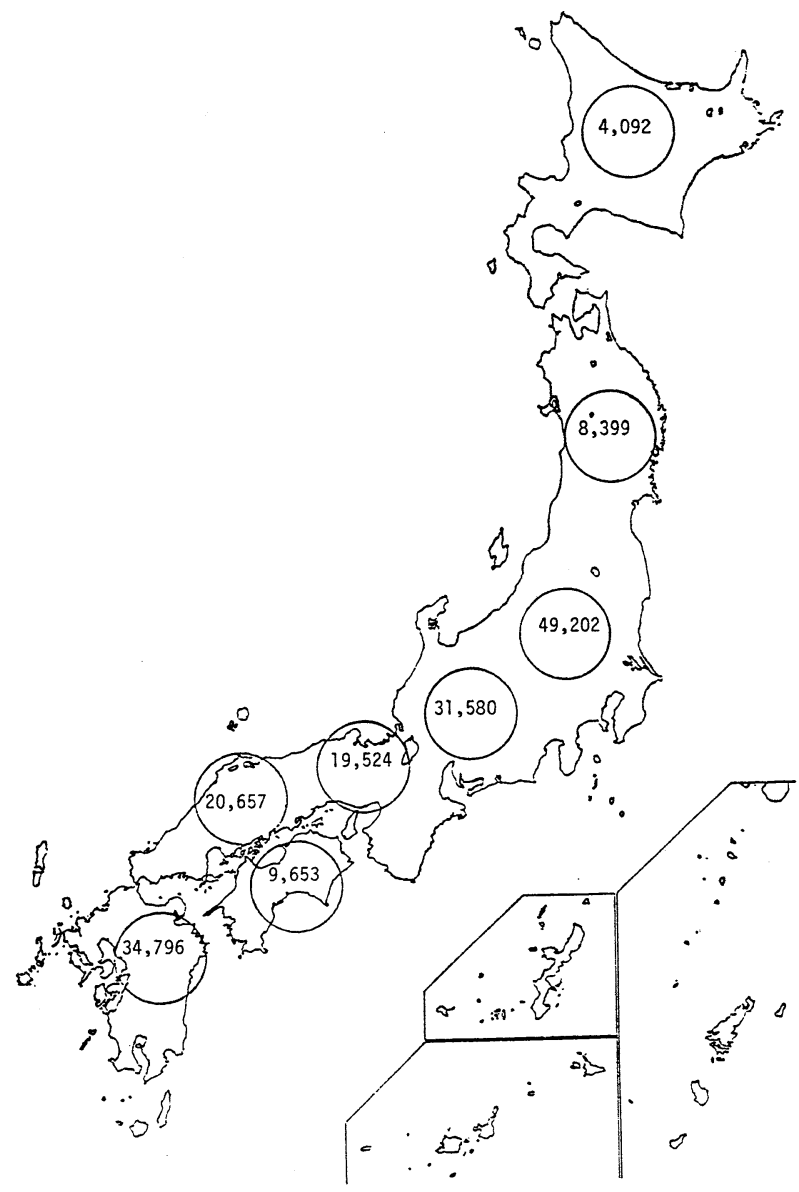

図 9-5 太陽冷暖房・給湯システム設置件数（昭和58年12月現在） ソーラーシステム振興協会調べ

表 9-5 公的施設におけるソーラーシステム補助金交付件数

\begin{tabular}{|c|c|c|c|c|c|c|c|}
\hline \multirow[b]{2}{*}{ 通産局 } & \multirow[t]{2}{*}{ 設の } & 福祉関係施設 & $\begin{array}{l}\text { 保健医療 } \\
\text { 関仵設 }\end{array}$ & 教育齐稚傜 & $\begin{array}{l}\text { 宿泊保盖 } \\
\text { 関係施設 }\end{array}$ & そ & 件 数 \\
\hline & & $\begin{array}{l}\text { 老人福祉センタ } \\
\text { 一, 保育所, 老 } \\
\text { 人ホーム, 身障 } \\
\text { 者養護施設等 }\end{array}$ & $\begin{array}{l}\text { 保健所, 病院, } \\
\text { 保健センター } \\
\text { 等 }\end{array}$ & 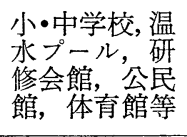 & 保健所等 & $\begin{array}{l}\text { 庁舎, 職員寮, } \\
\text { 清掃事務所, } \\
\text { 下水処理場等 }\end{array}$ & 計 \\
\hline 札 & 卧 & 16 & 5 & 15 & 1 & 5 & 42 \\
\hline 仙 & 台 & 27 & 10 & 11 & 1 & 6 & 55 \\
\hline 東 & 京 & 158 & 31 & 86 & 10 & 23 & 308 \\
\hline 名 & 屋 & 69 & 19 & 22 & 6 & 11 & 127 \\
\hline 大 & 阪 & 46 & 19 & 28 & 9 & 5 & 107 \\
\hline 広 & 島 & 44 & 14 & 22 & 0 & 6 & 86 \\
\hline 四 & 国 & 45 & 29 & 15 & 2 & 5 & 96 \\
\hline 福 & 岡 & 101 & 58 & 21 & 2 & 14 & 196 \\
\hline 沖 & 縄 & 4 & 2 & 3 & 0 & 0 & 9 \\
\hline 計 & & 510 & 187 & 223 & 31 & 75 & 1,026 \\
\hline
\end{tabular}


表 9-6 公的施設におけるソーラーシステム補助金額

\begin{tabular}{lcccccc}
\hline 年 & 度 & 昭和55年 & 56 年 & 57 年 & 58 年 & 計 \\
\hline 金額(億円) & 30 & 36 & 39 & 36 & 141 \\
\hline
\end{tabular}

方向を示していると言えよう。サンシャイン計画に抒 いても今後太陽熱発電用の高性能・低価格の機器特よ び材料の研究を指向することになっている。

一方熱発電システムの開発のブレイクスルーとして 電子技術総合研究所では熱電気複合システムの開発を 進め, 工業技術院筑波第 2 研究センターに昭和 57 年完 成した電気出力 $15 \mathrm{~kW}$ ，熱出力 $45 \mathrm{~kW}$ のプラントの運転試 験を引き続いて行っており，エネルギーコストを下げ る努力が進められている。

\section{4. 太陽電池}

太陽光発電技術の開発は現在各国共に太陽エネルギ 一研究開発プロジェクトの中で最重要項目のひとつと して強力に推進しつつある。おが国に㧤いても，サン シャイン計画では製造技術の分野では太陽電池用シリ コンの低廉精製プロセス扣よび太陽電池パネルの連続 大量生産技術の開発のため年間 $500 \mathrm{~kW}$ 規模の製造シス テムの建設を終って昭和58年には直江津, 日立, 尼崎, 姫崎および新座の 5 プラントの運転研究を進めた。ま たこれに伴う太陽光発電利用システムの研究のための 個人住宅( $3 \mathrm{~kW}$, 横須賀), 集合住宅 ( $20 \mathrm{~kW}$, 天理), 筑波大 学 $(200 \mathrm{~kW})$, 工場 $(100 \mathrm{~kW}$, 浜松) の運転研究を行ってい る。これと並んで集中型太陽光発電システムも市原の 分散配置型 (200kW) 括よび西条の集中配置型(1000kW) 2 システムが順次完成され，運転研究に入りつつあ る。また光・熱ハイブリッド型太陽光発電システムと して電気出力 $5 \mathrm{~kW}$, 熱出力 $25 \mathrm{~kW}$ 集光型ハイブリッド システムを開発して広島県坂町に和いて今後運転研究 に入るなど，太陽電池システムの実証化試験が急速に 進められつつある。

またアモルファス太陽電池については基礎研究は7 大学に, 連続生産技術の開発を民間 6 社に委託して素 子面積 $100 \mathrm{~cm}^{2}$ で光電変換効率 $8.25 \%$ が昭和 58 年で達成 され, 一般電力用として実用化に向けて低コスト製造 技術の開発が進められている。

以上の他にも II - V 属化合物半導体として CdS$\mathrm{CdTe}$ 系, $\mathrm{SnO}_{2}$ 太陽電池, 太陽電池の評価システム や，電力系統に組みこむための周辺技術なども並行し て進められている。

\section{5. 国際情勢}

太陽冷暖房・給湯分野ではIEA-CRD太陽冷暖房執 行委員会が 4 月スイスのベルン, 10月西独のフライブル
グで開催され，各国の開発政策の問題点を中心に討議 がなされた。また日豪技術協力では名古屋工業技術試 験所と豪州側 CSIRO が高級平板型太陽集熱器の試験 法について，また電子技術総合研究所と豪側 Telcom 社が太陽電池プラントの性能評価について情報交換を 進めている。

昭和58年 8 月には国際太陽エネルギー学会による太 陽エネルギー国際会議がオーストラリアのPerth で開 催され，約 1200 人の参加と 600 編に上る論文が提出さ れて活気のある会議となった。次回は1985年 6 月カナ ダのモントリオールの予定である。また国際太陽エネ ルギー学会日本支部の事務局は58年 7 月に名古屋工業 技術試験所太陽エネルギー研究室より日本太陽エネル ギー学会に移転された。

\section{3 海洋エネルギー利用技術の動向}

海洋エネルギー利用は，エネルギー資源がそしく， 国土の11倍という広い経済水域を持つわが国にとって きわめて魅力的であるが，従来のエネルギーにくら ベ，質が覀く，実用化までには，今後な沶相当な開発 努力が必要である。以下昨年の技術開発の進展につい て述べる。

\section{1. 波力発電}

海洋科学技術センタ一の第一期「海明」計画, 世界 最初の大出力波力発電実験は, IE A の国際協力のもと で実験に成功し，また実用化に必要な発電コストを引 下げるため改良すべき点も明らかになった。58年度か ら発電コスト 50 円 $/ \mathrm{kWh}$ の大型浮体形式波力発電装置 の設計手法を確立することを目的とする第二期計画が 発足した。本年は海域実験と水槽実験との比較, 理論 解析などにより船体の最適形状の設計手法, 船上装置 については, 空気出力向上のための位相制御およびタ 一ビン出力との関係, 無弁式タービンとこれまでのタ 一ビンとの比較, チューブポンプ式係留法など 60 年度 の海域実験のための研究が進められている。

また離島での実用化（目標発電コスト 40 円 $/ \mathrm{kWh）}$ を目的とする沿岸固定式波力発電システム（原理は前 に同じ）を新技術開発事業団が三井造船，港工業（鉄 製空気室と現地コンクリート工事), 富士電機(タービ ン発電機）の三社に開発を委託し，58年 9 月鶴岡市郊 外の立岩地区に完成した。空気室は左右を岩礁で支兄 られた, 輻 $8 \mathrm{~m}$, 高さ平均海面から $5 \mathrm{~m}$, 前縁は約 70 
cm海中に入った底なしコンクリート箱である。タービ ンの直径は $1.3 \mathrm{~m}$ である。発電機の定格出力 $40 \mathrm{~kW}$ （波 高 $2.4 \mathrm{~m}$ ）の設計值は 充分達成し, 月平均出力も海の 荒れる冬に向ってら充，8.8kW（10月)，13.7kW(11月), $18.7 \mathrm{~kW}$ (12月) といら結果が得られた。もし平均出力 が年間 $10 \mathrm{~kW}$ 得られるならば, この設備の発電コストは 40円/kWhとなり，ディーゼル発電よりも安くなる。 しかし商用電源とするためにはディーゼル発電との組 み合わせなどによって, 出力, 周波数の安定化が必要 である。

英国ではエネルギー省の予算で引続き CLAM と D UCK の大型模型による試験が 行われているが，この 他に工業省と民間の共同により，北スコットランドで わが国のものとほぼ同じの原理で, 出力 $4000 \mathrm{~kW}$ の防波 堤組込式の波力発電システムが予算60億円， 3 年計画 で進められている。

ノルウエーも活発で現在は位相制御方式, 波エネル ギー集中方式の研究が進められている。

米国はDOEの予算カットの関係も方，マッュー ミックが水槽による1/4スケールモデルで波／電気の変 換効率37\%という高い值を得ているが，ロッキード社 のダムアトール方式は進展していない様子である。

\section{2. 海洋温度差発電 (OTEC)}

サンシャイン計画の $1000 \mathrm{~kW}$ 洋上パイロットプラント 計画は58年度も着手するに到らず，引続き工技院傘下 の研究所などで準備研究が進められている。電総研で は洋上プラントの場合, 季節や昼夜による水温変動, 海象の変化による動摇のために括こる，発電特性の変 化を調ベるため三式のシュミレータ，(1)給水の温度や 流量をプログラムで変化できる熱源装置，(2)その水を 使用して発電する装置 (ETL-OTEC-III) および, (3) 熱交チューブに振動を与えた状態で伝熱特性を調べる 装置，による実験を進めている。入力の動的変化はい つかの要素特性に直接間接に時間遅れを伴う変化を与 え, 発電システムの性能変化はかなり複雑であること がわかってきた。

四国工試は造波，環流水槽などを使い洋上プラント の深海係留法を調べて括り，カテナリ一係留とテンシ ヨン係留を比較し，後者の方が勝っていること，また それに適するゴムと鋼索を組み合わせた高耐衝撃係留 索の開発を行っている。

このほか佐賀大学ではプレート熱交, 東海大学など では冷水取水管（CWP）についての基礎研究が行わ れている。

産業界ベースでは，九州電力の $50 \mathrm{~kW}$ ハイブリッド型
OTEC が徳之島で発電実験に成功した。新徳之島ディ 一ゼル発電所の廃熱を高温熱源とし， $300 \mathrm{~m}$ の 深さか ら水温 $11^{\circ}-16^{\circ} \mathrm{C}$ の泠海水を硬質ポリエチレン管（管長 $2,350 \mathrm{~m}$, 内径 $50 \mathrm{~cm}$, 肉厚 $2.5 \mathrm{~cm}$ ) で汲上げて低温熱源 とした。ただし設計最大波高 $11 \mathrm{~m}$ に耐えるため, 水深 $30 \mathrm{~m}$ では鋼管とし，海底に埋設した。ポリエチレン 管の部分の敷設法はナウルの場合と似ている。タービ ンは単段ラジアルフロー型アンモニアタービンが使用 されている。これでわが国は，フレオン（ナウル）と アンモニア両媒体の 海洋発電経験を持ったわけであ る。得られた総出力は $50 \mathrm{~kW}$ この内 $32 \mathrm{~kW}$ ご所内動力と して消費された。新徳之島発電所が海抜 8-9 $\mathrm{m}$ にあ る為海水ポンプ動力が大きく，仮に海抜 $0 \mathrm{~m}$ に設置で きれば所内動力は $20 \mathrm{~kW}$ 減るはずと推定されている。

米国では政権交代以降, 相変らず DOEは OTEC に消極的ではあるが，オアフ島の 40MW 級の OTEC 実証プラントを設置するプロジェクトは進行してい る。フェーズIの概念設計 (83年年報参照) に関する, G E， O T Cの両社の報告書を検討した結果， O T C 社が選ばれ，フェーズII（83年 6 月一-84年12月）に入 った。同社が選ばれたおもな理由は現有技術の延長上 にあり,リスクは少ない。プラントに隣接する火力発 電所の排熱で表面海水を加熱しサイクル効率を上げ, 発電コストを下げる配慮がされている。また建設費は D O Eの期待した枠内にあったことなどとみられる。 ただし CWP(深海部：直径 $6.6 \mathrm{~m}, 3000 \mathrm{~m}, \mathrm{FR} \mathrm{P}$ 製 ; 急斜面部：直径 $7.8 \mathrm{~m}, 420 \mathrm{~m}$ 長, 鋼製; 浅海部 : 直 径 $7.8 \mathrm{~m}, 1050 \mathrm{~m}$ 長, コンクリート管埋設）は巨大で, とくに急斜面部の敷設法など未経験の部分があり，大 変な技術開発努力が必要ということを指摘している。 今後この計画が順調に進めば，86年建設着手，88年か ら稼動する見込である。

この他ハワイでは，この発電所の CW P の耐海洋性 をしらべるため，この CWPの1/3モデル（直径 $2.5 \mathrm{~m}$, 長さ $122 \mathrm{~m} ，$ F R P）をMINI-OT E Cバージから海 中に吊下げ実海域に抢ける応力の測定とハワイ島海辺 の実験所において,オープンサイクル方式の基礎実験, 熱交チューブの生物污れの試験, 深海水利用養殖の試 みが行われている。

フランスはOT E C開発を 2 年間中断していたが, 83年再び開始した。熱帯域の仏領諸島の電力自給を目 的とし，タヒチ島に $5 \mathrm{MW}$ 級の O T E C プラントを86 年から建設するための準備研究，すなわち83年から 3 年計画（予算 $60 \mathrm{MF} \mathrm{F}$ ) で，オープン/クローズド方 式の比較，プラント設計，必要技術開発などが再開さ 
れた。

\section{3. その他の海のエネルギー}

科学技術庁研究調整局が中心になり各省庁共同の 「黑潮の開発利用の調査研究」が進められてきた。そ の内, 海洋科学技術センターは黒潮エネルギーの賦存 量招よび変動の調査観測, 海流発電に適する強潮流地 点の調查, 3 翼サポニアス水車型発電模型の大型水槽 や海域実験の実施，設置に伴う影響のアセスメントな ぞが進められて和り，たと党ば本流の強さ，方向，位 置も時間的に変動するので, 水車タービンは風力タ一 ビンのように常に主流の方向に向くようなものでなけ ればならないことなどがわかった。

米国にはフロリダ海流中に大型特殊な水車タービン を沈めて発電を行らコリオリス計画があるが，昨年は あまり進展がみられなかった模様である。

この他，わが国では海洋汇ある地熱資源探査開発の 基礎調查 (サンシャイン計画総合研究)が始められた。 米国ではアリニーシャン列島の地熱 $\left(150-180^{\circ} \mathrm{C}\right)$ と周 辺海水 $\left(\sim 5^{\circ} \mathrm{C}\right)$ との温度差を利用したハイブリッド 型発電 (GEOTEC) の試設計が行われ, 出力 10-12 MWe プラントで建設費 4100 ドル $/ \mathrm{kWe}$ ，発電原価 9.3 セント $/ \mathrm{kWh}$ となり経済性があると報告された。

\section{4 バイオマス利用技術の動向}

\section{1. はじめに}

近年，代替エネルギーの開発が世界的に盛んに行わ れている。バイオマス資源は再生可能であるため, 液 体然料（エタノール，メタノール，ブタノール）や気 体燃料（水素, メタン) の原料として注目されている。 たとえば，第 7 回国際生物工学シンポジウムが，イン ドのニューデリーで本年 2 月19日〜25日まで開催され たが，バイオマスエネルギーに関連して，多くの発表 があった。その中の主要なものを紹介するとマイアミ 大学の三井ら ${ }^{1)}$ は, 太陽エネルギーと藻類や光合成細 菌などを利用して, 水素を生産するシステムの基礎研 究について一連の研究成果を発表した。るた Lehigh 大学の A.E.Humphreyら 2)は, 微生物による液体燃 料, とくにエタノ一ルの生産について検討し, エタノ 一ルの用途, 原料の多様性, またエタノールの蒸留の エネルギーコストなどあらゆる方面から発表した。 Institute of Gas Technology の S. Ghosh ら³ 微生物による気体燃料（メタン, 水素）の生産につい
て検討し, エネルギー効率, 原料の前処理, リアクタ 一設計などバイオガス生産のためのトータルシステム についての発表があった。以上のように, バイオマス エネルギー変換・生産関連の研究は世界的に盛んに行 われている。ここでは1983〜1984年の間に発表された バイオマス燃料関係の研究開発の動向について概説す る。

\section{2. 液体燃料}

エタノール, メタノール, ブタノールなどのアルコ 一ルは, 自動車然料や燃料増量剤などとして期待され ていることはよく知られている。とくにエタノール然 料は，1）エタノ一ル発酵技術は古くから確立されて いる，2）大規模プラントでも資金負担が比較的少な いこと，3）蒸留工場が環境污染の原因にならないこ となどから，然料として有望視されている。とくにブ ラジル，アメリカなどでは，国家的プロジェクトとし て大型のェタノール発酵プロジェクトが推し進められ ている。

\section{1 エタノール}

わが国でも新エネルギー総合開発機構（英文名 $\mathrm{NE}$ DO, New Energy Development Organization) が，昭和55年10月に石油代替エネルギー開発の中核的 推進母体として設立された。石油代替エネルギーの技 術開発の中に燃料用エタノールの技術開発があり, エ タノールの生産が，国家的プロジェクトとして推し進 められている。このプロジェクトは, 新製造プロセス の開発や未利用資源の開発, アルコール製造コストの 大幅な低減，供給量確保のための幅広い技術開発など でわが国での然料用アルコールの広範围にわたる実 用化を目指すことを目標としている。

わが国のよらに狭い国土では農産資源も乏しいの で, アルコール発酵の原料を広範囲に求め, バイオマ スを有効に利用しなければならない。アルコール発酵 の原料として考觉られるのは, 糖質系バイオマス, デ ンプン質系バイオマス，セルロース系バイオマスなど である。

セルロース系バイオマスは, いずれる酸や醭素を利 用して糖化しなければならない。したがって糖化率を 上げるため，前処理方法や糖化処理条件の検討が盛ん 飞研究されている。

たとえば，脱脂木粉を水の存在下密閉状態で周波数 2, 450MHzのマイクロ波で加熱し, 続いて溶媒抽出す るとセルロース，へミセルロース拉よ゙リグニンの主 要 3 成分の分別が可能となる。マイクロ波加熱による 前処理後, 酵素糖化を行ったところ, 還元糖はマイクロ 
波処理温度が $160^{\circ} \mathrm{C}$ 以上で 顕著に生成し， $223 \sim 229^{\circ} \mathrm{C}$ で最高值を示した。最高糖化率はブナの場合 $93 \%$ ，竹 は $85.7 \%$,赤松は65.6\%であった の粉に 50Mradの $\gamma$ 線を照射すると相当量の還元糖が 生成し，デンプンの分解も起こった。 $r$ 線を用いて前 処理したトウモロコシ粉をアミラーゼ処理すると, 約 12.5\%の還元糖が得られた。熱処理方法に比べると 線処理方法は培地の殺菌の必要もなく, 基質の粘性も 高くならず有利な方法であることがわかった5)。

木粉を高圧塩化水素ガス下で加水分解( 1 時間, 315 psia）し, さらに希釈塩酸で加水分解すると, グルュ 一スは収量80\%で，キシロースは収量95\%で得られた 6)。またセルロース系バイオマス（稲わら，バガス， 木片) を $200^{\circ} \mathrm{C}, 3.45 \sim 13.8 \mathrm{MPa}$ の高纴二酸化炭素で 前処理すると加水分解の効率が上がり, 可溶化が容易 になった。なお，二酸化炭素を高圧化するために必要な エネルギーを計算すると, $3.45 \mathrm{MPa}$ でバイオマス $1 \mathrm{t}$ あたり $11 \mathrm{KWh}$ W゙あった7)。さらにリグノセルロース系 バイオマスをオゾン処理すると, セルラーゼによる加 水分解やルーメン細菌による分解が促進され，動物飼 料やグルコースを生産するのに有利となる。そこでこ のオゾン処理条件を検討した結果, バイオマス乾重量 の 4 〜 6のオゾンガスを 1 ～ 2 時間バイオマスと接 触させることが有効であっだ8。

一方，セルロース系バイオマスから直接エタノール などを生産させる研究も盛んに行わ机ている。Acetivibrio cellulolyticus は，セルロースを直接資化してエ タノール, 酢酸, $\mathrm{H}_{2}, \mathrm{CO}_{2}$ を生成する。培地の $\mathrm{pH}$ を 6.8 亿すると, 酢酸よりもエタノールが打もに生産さ れ, 培地に補助還元片を添加すると, さらにエタノ一 ル生産量が増加する。エタノール存在下で培養しても, 増殖時に溶菌が起こるが, 非増殖時にはこれが起こら ないことがわかった。元の菌株より 7 倍も高濃度のエ タノール中で増殖できる安定菌株も得られた ${ }^{9)}$ 。た， 酵素によるセルロースのグルコースへの加水分解とェ タノール発酵とを組み合わせた同時糖化発酵法は, 生 成したグルコースによる阻害がなく，糖化と発酵を別 々のリアクターで行ら必要がないなどの利点があり, 多くの研究がなされている。さらにPenicillium funiculosum セルラーゼとェタノール生産菌の Saccharomyces uvarum との適合性と，S. uvarum を多孔性ゼ ラチンゲル中に固定化し，これを用いるシステムによ るセルロースからエタノールの加水分解・発酵システ ムについても検討されている10)。

以上のように，セルロース系バイオマスからのエタ
ノール生産システムは液化, 糖化など前処理法が必要 となるが，未利用のバイオマスの有效利用にきわめて 重要である。

デンプン質系バィオマスの場合にも，あらかじめ液 化, 糖化して微生物の資化可能なグルコースなどに変 換しなければならない。そこでデンプンを効率的に液 化, 糖化することが重要であり, 固定化グルコアミラー ゼの利用などが, 以前から検討されている。ここではと くに，デンプン質資化性酵母の検索同定や生物工学的 手法によるデンプン質発酵性酵母の育種について紹介 する。三重大学の赤木ら ${ }^{11}$ は, 土壌より生デンプンの資 化性の優れたデンプン資化性酵母を検索し, 菌体外グ ルコアミラーゼ生産能の強い一菌株を得て, これを Rhodosporidium sp. と同定した。この菌株に紫外線 を照射して得た J-5B株の生産するグルコアミラーゼ は，酸安定性和よび生デンプン質分解活性が優れてい た。大阪大の坂井ら ${ }^{12}$ は, Saccharomyces diastaticus I F O 1046 株を変異原処理して得られた 251 株はデン プン発酵能が優れているが，エタノールは理論収率の 約60\%と低かった。この原因は，この菌株のアミラー ゼがデンプンを完全に分解できないためであることを 見出した。そこで, デンプン分解能の高いアミラーゼを 生産する酵母 Saccharomycopis tibuligera I F O0106 を用いて両酵母を融合させて，エタノールの収率向上 について検討している。広島大福井 ${ }^{13}$ らは, Saccharomyces diastatius のグルコアミラーゼ遺伝子 (STA 1, $S T A$ 3）をクローン化し, S. cerevisiae を形質転換し たが，プラスミドは非選択条件下で脱落しやすいなど の欠点がある。そこで染色体D NAに 100 コピー程度 存在する $\delta$ 配列にグルコアミラーゼ遺伝子を挿入する ことにより, 遺伝子の安定化とグルコアミラーゼの量 産を試みている。

糖質系バイオマスは，これに酵母などを作用させる とこれから直接エタノールが生産でさるので，バイオ マスのらちでは利用しやすいもののひとつである。た と党ば22種類の酵母をスクリーニングした結果, グル コースとセルビオースの両方を発酵する Candida lusitaniae (NRRL Y-5394)と C.wickerhamii (NRRL Y-2563）を得ることができた。この両株は, セルビオ 一スからエタノールを生産する初速度が速く, C. lusitaniae $90 \mathrm{~g} ・ \ell^{-1}$ セルビオースを用いて 5-7 日間 で44g・五のエタノールを生産したが, エタノール濃度 が $45-60 \mathrm{~g} ・ \ell^{-1}$ になると発酵は停止した。また, C.wickerhamii む C.lusitaniae と同様の発酵速度を示すが, エタノール 濃度 $20 \mathrm{~g} ・ \ell^{-1}$ で発酵が停止した。また， 
Trichoderma reesei の ルララーゼと Saccharomyces cerevisiaeを組み合わせたシステムで，セルビオース からのエタノール取率をコントロールした場合，エタ ノール収率は10-30\%に達した ${ }^{14) 。 ま た K l u y v e r o m y c e s ~}$ fragilis を用いてチーズホエイのラクトースから連続 菌体循環発酵によってエタノ一ルを生産したところ, 希釈率が $0.15 \mathrm{~h}^{-1}$ で, 最大生産量が $7.1 \mathrm{~g}$ エタノール $\ell^{-1} \mathrm{~h}^{-1}$ で, 残糖はほぼ完全に消費された ${ }^{15)}$ 。

一方効率的にエタノールを生産させるために，バイ オリアクターの設計，菌体の固定化方法などの検討も されている。生産されたェタノールの影響を除くため に, チューブ状の発酵槽に S. cerevisiae (NRRL Y 132）を固定化したところ，エタノール濃度が76-60 g ・ $\ell^{-1}$ になっても21.2-83.7g・ $\ell^{-1} \mathrm{~h}^{-1}$ でェタノールを 生産することができた。この収率は，0.5 gエタノ一 ル $\mathrm{g}^{-1}$ グルコースに相当する16)。

固定化酵素を用いるエタノールの生産は，パイロッ トスケールで行われている。ここでは, 新然料油開発 技術研究組合の成果を紹介しよう。鮫島ら ${ }^{17}$ は, 酵母 菌体をアルギン酸カルシウムゲル中に包括固定化し, これを流動床型りアクターに適用した。このシステム は2台のリアクターから構成されており，酵母を含む アルギン酸カルシウムゲルはリアクター内で製造さ れ，その反応に利用できるようになった。原料として 廃糖蜜が用いられた。8-9（v/v）\%のエタノールを生 産するシステムでは，通塔速度0.4-0.5（対ゲル容量） にて4000時間の安定生産が行われた。エタノールの生 産性はリアクター $1 \ell$ 当り17-20 g エタノール/時間で あり, 純エタノール換算で約 $0.6 \mathrm{k} \ell / \mathrm{k} \ell$ (リアクタ一容 量)・日で，バッチ法の17-20倍であった。対糖転換収 率は, 理論值の約 $95 \%$ あった。さらに10klのバイオ リアクターも完成し，運転が行われた。このように固 定化酵母を用いる利点は, リアクタ一容量当りのアル コール生産性の高さにあるが，その他にも設備費や人 件費の削減をできるメリットもある。

一方 Zymomonas mobilis は, 酵母に比べてアルコ 一ル生成速度が速いことが知られて扣り, 注目されて いる。Z. mobilis についての最近の報告を紹介する。 Concanovalin A-Sepharose に固定化した $\beta$-Dglucosidase と Z. mobilis を共にアルギン酸カルシ ウム中に固定化すると，バッチ方式でも連続フローシ ステムでもセルビオースからエタノールを生産できた 18)。大阪府大(農)の外村ら ${ }^{19)}$ は, Zymomonas を分子 育種する一連の研究を行って和り，Zymomonas へ異 種遺伝子を導入する方法の開発を行っている。すなわ
ら薬剤耐性プラスミドR68.45を用いて, ラフィノース 発酵能を担うプラスミドpOD 1188 Pseudomonasに 移し，遺伝子を組み換えた後，これをZymomonas に 移す研究をしている。

\section{2 メタノール, ブタノール}

メタノールやブタノールの生産に関する研究は, エ タノールの研究に比べその数は少ないが, バイオマス を高度に有効利用するためには必要である。メタノ一 ルの生産に関しては, Methylomonas methanolovarans の培養特性が，バッチ法と連続培養法で調べられ ている20)。一方, Clostridium acetobutylicum(ATCC 824)の野生株は, ブタノールが $15 \mathrm{~g} ・ \ell^{-1}$ で生育阻害を 起こすが，S A-1変異株は生育阻害をらけず，高濃度 のブタノール $(5 \sim 14 \%)$ が存在しても, ブタノール を生産する。しかしアセトンの生産に関しては, 野生 株の方が優れていた ${ }^{21)}$ 。またアセトン，イソプロパノ ール, nーブタノールを生産する菌株をスクリーニング したところ, Clostridium beijerinckii と C.aurantibutyricum が少なくとも，40mMの $\mathrm{n}$ ーブタノールを生 産した ${ }^{22) 。}$

\section{3. 気体燃料}

水素やメタンなどのバイオガスをバイオマスから生 産する研究も最近盛んである。以前から廃棄物処理工 程で実用化されていたメタン発酵は, 積極的にエネル ギー生産システムとして見直されており，世界的に盛 んに研究が行われ, 廃棄物バイオマスのエネルギー化 に重要な役割を果たすと期待されている。一方, 水素 はクリーンなエネルギーとして注目されて和り，バイ オマスから水素を生産するシステムの開発もきわめて 重要である。ここでは, 筆者らのバイオガスの生産に 関する研究を紹介する。

\section{1 水 素}

水素はクリーンなエネルギーであり，これを安価に 生産する研究が世界的に盛んに行われている。筆者ら はすでにCitrobacter freundii を固定化し（厚紙中に

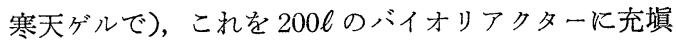
し，これを用いて毎分0.6lの水素を生産させることが できた ${ }^{23)}$ 。さらに水素の生成能を向上させるために は, 遺伝子工学を利用して水素産生菌のヒドロゲナー ゼ系のクローニングを行い，水素生成能の高い微生物 を分子育種するか, 微生物を組み合わせてバイオマス からの水素生成効率を改善するかである。前者沈つい てはC. freundii のヒドロゲナーゼのEscherichia coli 中でのクローン化 ${ }^{24)}, E$. coliのヒドロゲナーゼのセル フクローニングなどに成功し, 現在 C.freundii のホ 


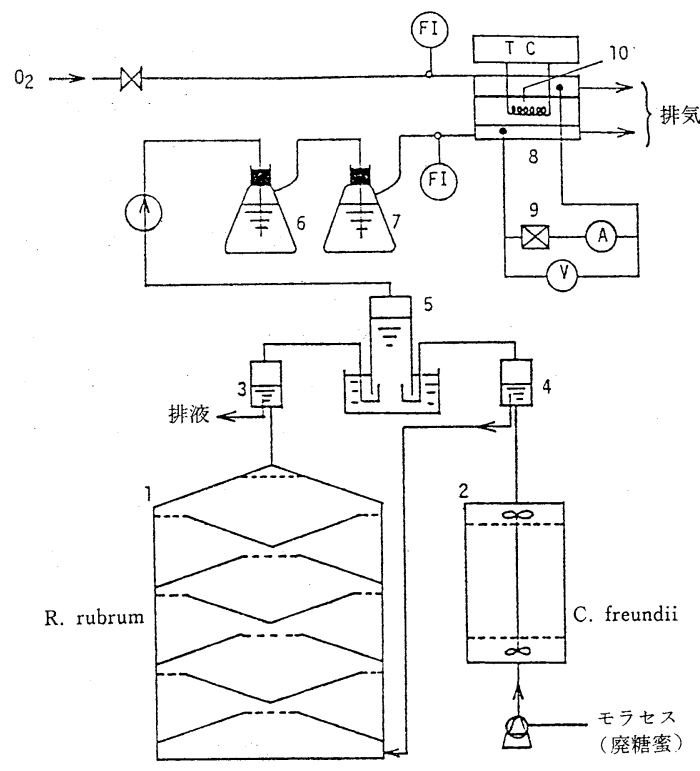

1. 固定化光合成細菌用バイオリアクター

2. 固定化水素生産菌用バイォリアクター $3 \sim 5$. 水素りザーバー

6. トラップ ( $\mathrm{KOH})$

7. トラップ（水）

8. リン酸型燃料電池

9. 可変電子負荷

10. ヒーター

図 9-6 固定化光合成細菌, 固定化水素生産菌リアク ターと電池システム

ストーベクター系の開発を行っている。

一方後者の場合は, C. freundii が水素以外に䣷酸, 酪酸，乳酸などの有機酸を副生するので，これからさ らに水素を生成させようとする方法で, 光合成細菌の 利用が考允られる。

そこで光合成細菌のRhodospirillum rubrumを $2 \%$ のアルギン酸カルシウムゲル中に固定化し，これを20 $\ell$ リアクターに13kg充填した。一方, C. freundii
同様にアルギン酸カルシウムゲル中に固定化し，この ゲル $2 \mathrm{~kg}$ を $5 \ell$ のバイオリアクターに入れた。これら のシステムを図 9-6に示す。基質として廃糖蜜50倍希 釈液（糖含量 $2 \%$ )を $600 \mathrm{ml} \mathrm{h} \mathrm{h}^{-1}$ の流速で固定化水素産 生菌リアクターに送り，水素の生成を行わせ，さらに このリアクターから得られる廃液を固定化光合成細菌 リアクター (5000ルックスの光照射下に設置)に送り， 水素の生産を行わせた。得られる気体と廃液は気液分 離装置で分離して，バイオガスを得た。このリアクタ

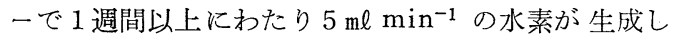
た。このように固定化水素産生菌と光合成細菌を組み 合わせると，バイオマスの水素への変換率を $10 \%$ 以上 あげることができた $251 。$

一方，有機物を必要としない水素生産システムとし てらん藻が注目されている。筆者らは，固定化らん藻 と光エネルギーを用いる水素生成に関する一連の研究 も行っている。らん藻の Anabaena sp. N-7363を кカラギーナンゲル中に固定化した。これを（13kg） 25 ものアクリル製の透明なリアクター（図 9-7）に入れ て, 気相を二酸化炭素と窒素の混合ガスで置換した。 40 時間の前培養後, 気相をアルゴンに置換した。固定 化らん藻を含む 3 台のリアクターを用い, 光照射下で 反応を行わせたところ，1分間当り0.5-1.1 $\mathrm{ml}$ の水素 が生成し，水素生成速度は 0.034-0.076 $\mu$ moles $\cdot \mathrm{g}^{-1}$ (wet gel)h-1 であった ${ }^{26)}$ 。こように, 光エネルギ 一のみで水素を生産させることも可能であるが，水素 の生成量が低い問題があり，これを改良するのが今後 の問題である。

\section{2 メタン}

可溶性有機物からエネルギーを回収するメタン発酵 プロセスが注目されている。このメタン発酵を効率化 するには, 発酵槽内のメタン生産菌群の高密度化が重 要な課題のひとつとなっている。そこで筆者らはスラ ッジのままのメタン菌を用いるリアクターを試作し

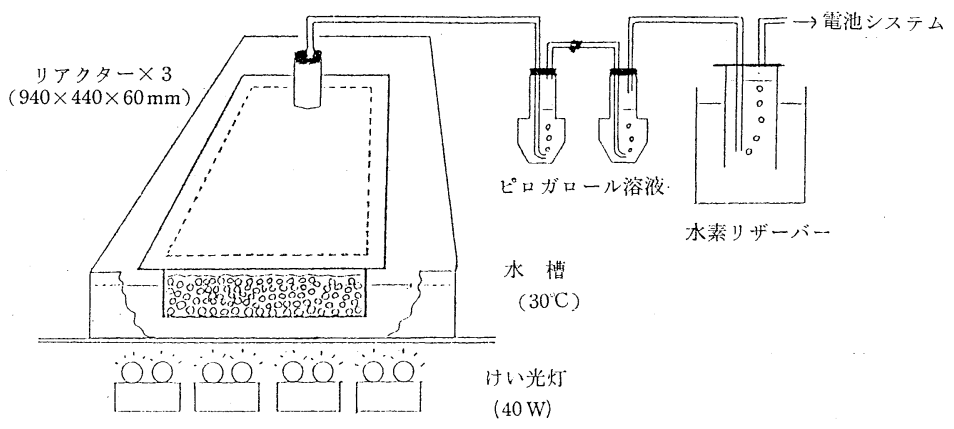

図 9-7 固定化らん藻リアクター 
た。同時に微生物の流出を防止するための固液分離装 置を新たに考案し, これをリアクターに装着し, 菌体 の高密度化を図り，このシステムを用いてメタンの連 続生産を行った。

メタン生産菌群を含むスラッジを反応槽 (160m ) 飞 入れ， $\mathrm{pH} 6.7$ 亿調整した基質を移送した。バイオガ ス生成量は最初 $0.29 \ell$ バイオガス $\mathrm{g}^{-1}$ ・CODであった が, 25 日後には $0.36 \ell$ バイオガス $\mathrm{g}^{-1} \cdot \mathrm{COD}$ に増加し た。この間メタン濃度は55-56\%でほぼ一定であった。 また最終的C OD除去率は約70\%であった。このシス

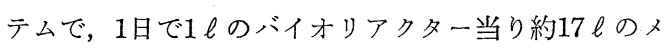
タンが生成することがわかった ${ }^{27) 。 こ の よ ら に, ~ メ タ ~}$ ソ生成速度执よびメタン生成効率がともに増大してい くことがわかった。これは基質を連続的に供給し，固 液分離装置で菌体を連続的に回収することにより，メ タン 発酵を行うために適切な微生物が 選択的に増殖 し，良好にリアクタ一内に保持されたためと考觉られ た。

\section{4. おわりに}

以上, 最近のバイオマス燃料の研究・開発の動向に ついて述べてきた。この分野の研究は年々盛んになっ ているが，バイオマス原料を何にすべきかが課題で㐫 る。わが国のような資源の乏しい国では，とくにこの 問題を考慮しなければならないであろう。遺伝子操作 技術によるきわめて成長の速い植物の育種や海洋性バ イオマスの有效利用を, むっと積極的に進めなければ ならないと考光られる。

\section{文献}

1) Mitsui, A., VIIth International Biotechnology Symposium Vol. I, p. 24-25 (1984)

2) Humphrey, A.E., et al., ibid., p. 26-28

3) Ghosh, S., ibid., p. 29-32
4) 東 順一, 化学々生物, 22, 146 (1984)

5) Han, Y.W., et al., Biotechnol. Bioeng., 25, 2631

6) Antonoplis, R.A., et al., ibid., 25, 2757

7) Puri, V.P., et al., ibid., 25, 3149

8) Neely, W.C., ibid., 26, 59 (1984)

9) Armstrong, D. W., et al., ibid., 25, 2567

10) Deshpande, V., et al., ibid., 25, 1679

11）赤木盛郎，他，日本農芸化学会誌，58，153 (1984)

12）坂井拓夫, 他, 昭和 59 年度日本農芸化学会大会, 要旨集, p. 80

13）福井作蔵, 他, 昭和 59 年度日本農芸化学会大会, 要旨集, p. 81

14) Freer, S. N., et al., Biotechnol. Bioeng., 25, 541

15) Janssens, J.H., et al., ibid., 26, 1 (1984)

16) Gencer, M. A., et al., ibid., 25, 2243

17) 鮫島廣年, 酵素工学研究会第11回講演会, 講演要 旨集, p. 7 (1984)

18) Lee, J. M., et al., Biotechnol. Bioeng., 25, 2441

19）外村健三, 他, 昭和59年度日本農芸化学会大会, 要旨集, p. 245

20) Amano, Y., et al., Biotechnol. Bioeng., 25, 2735

21) Lin, Y.L., et al., Appl. Environ. Microbiol., 45, 966

22) George, H. A., et al., ibid., 45, 1160

23) Suzuki, S., et al., Ann. N.Y. Acad. Sci., 413, 133

24) Karube, I., et al., FEBS Lett., 158, 119

25）軽部征夫, 他, 日本化学会第 48 秋季年会, 講演要 旨集, p. 271

26）軽部征夫, 他, 電気化学協会第51回大会, 講演要 旨集，p. 75 (1984)

27）軽部征夫, 他, 日本化学会第 48 秋季年会, 講演予 稿集 I, p. 270 


\section{一他 学 協 会 会 告-}

本会共催

\section{A S オンライン説明会・講習会}

主催 (社)化学情報協会

日時・説明会 9 月 4 日(火) 18 日(火)

$14: 00 \sim 16: 00$

・講習会 $\mathrm{CA}$ ファイル基礎

9 月 5 日(水) $\cdot 12$ 日(水) $\cdot 19$ 日(水)

REGISTRYファイル基礎

9 月 6 日(木) $\cdot 20$ 日(木)

$\mathrm{CA}$ ᄀァイルデータベース

9 月13日(木)

受講料・定員

- 説明会 無料 9 名

・講習会 CAファイル基礎 10,000円 6 名,

REGISTRYファイル基礎

15,000円 6名, CA ファイルデー

タベース 10,000円 20名

問合先・申込先

（社）化学情報協会 講習会受付係

東京都文京区弥生2-4-16 電話（03） 816-3462

\section{本会協賛}

\section{第 582 回講習会＝最近の集塵技術}

日 時 昭和59年 9 月 6 日(木), 7 日(金)
9. $30 \sim 17.00$

会 場 ダイヤモンドホール

（ダイヤモンド社ビル10階）

題 目

9 月 6 日(木)

(1) 浮遊粒子状物質対策の動向

(2) 集塵技術の展望と最近の話題

（3）電気集塵技術の最近の動向

(4) 滤過集塵技術の最近の動向

(5) 集麼設備の計画
油化学 講演 会

一油化学と最近の有機合成一

主 催 (社)日本油化学協会

日 時 昭和 59 年 9 月 25 日(火) 13 時 17時

会 場 日本化学会講堂

演題と講師

1. 遷移金属化合物を用いる有機合成 一パラジ ウムの反応と特徵と応用一

(東工大学工) 过 二郎

2. ファインケミカルズのための $\mathrm{C}_{1}$ 化学

(化技研) 田中 正久

3. クラレ法テルペン製造技術とその開発所感

（クラレ）糸井 和男

参加費 : 有料

問合先：(社)日本油化学協会

于103 東京都中央区日本橋3-13-11

油脂工業会館 7 階

電話０3-271-7463
9 月 7 日(金)

（6）集塵装置性能試験法

（7）製鉄所における集塵装置及びその管理

（8）火力発電所飞扮ける集鹿装置とその管理

（9）セメント工場に抢ける集塵装置及びその 管理

(10) 最近の廃棄物焼却炉用集塵装置

定員 100 名

聴講料 有料

問合先・申込先

干151 東京都渋谷区代々末2-4-9

(三信北星ビル 5 階)日本機械学会 